\title{
Correction to: Navigating cultural differences during the delivery of behavior analysis services in Austria
}

\section{Marie Hélène Konrad ${ }^{1} \cdot$ Andresa A. De Souza ${ }^{2}$ (1)}

Published online: 18 January 2022

(c) Association for Behavior Analysis International 2021

\section{Correction to: Behavior and Social Issues https://doi.org/10.1007/s42822-021-00077-9}

The surname of the second author was misspelled in the published version. The correct spelling is "De Souza" instead of "Souza."

The appendix that represented the "Cultural Background Questionnaire" was not included in the published version. It was added afterwards.

The postal address of the first author has been removed for personal data protection reasons.

We apologize for this error.

The original article has been corrected.

The original article can be found online at https://doi.org/10.1007/s42822-021-00077-9.

Marie Hélène Konrad

mariehelenekonrad@gmail.com

1 Autismuszentrum Sonnenschein, Sankt Pölten, Austria

2 College of Education, University of Missouri - St. Louis, St. Louis, MO, USA 


\section{Appendix}

\section{Cultural Background Questionnaire}

We developed this questionnaire to learn more about your family as we strive to provide services in a way that is meaningful for you and your family. Furthermore, we want to make sure we respect and honor your preferences around the intervention process.

This questionnaire is optional. Your decision to not complete this questionnaire or the answers you provide will not affect your ability to receive services in any way. Feel free to provide as much information as you would like.

\section{Parent/Caregiver}

Name:

Preferred Pronouns: She/Her/Hers - He/Him/His - They/Them/Theirs

Marital Status:

Relationship with the Child:

City and Country of Birth:

Nationality:

Known Disabilities:

Accommodations Needed: $\square$ Audio Recommendations

$\square$ Large Font

Visual Recommendations $\square$ Extended time during training

$\square$ Special Lightning

$\square$ Others:

Faith or Religion:

Holidays You and Your Family Celebrate:

Traditions You and Your Family Practice: 


\section{Household Information}

Number of people living in your household:

Relationship with your child:
$\square$ Siblings
$\square$ Grandparents
$\square$ Cousins
$\square$ Friend of the family
$\square$ Aunts/Uncles
$\square$ Others:

\section{Language Information}

\section{Country of Origin}

Name:

Language(s) spoken:

How long did you live in the Country of Origin?

\section{Country of Residence}

Language(s) spoken:

How long have you been living in the Country of Residence?

Languages:

Native Language:

Language(s) spoken at home:

In the table below, select the language(s) you can speak, understand, read, or write well. Add other languages that you use.

\begin{tabular}{|l|l|l|l|l|}
\hline German & $\square$ Speak & $\square$ Understand & $\square$ Read & $\square$ Write \\
\hline English & $\square$ Speak & $\square$ Understand & $\square$ Read & $\square$ Write \\
\hline & $\square$ Speak & $\square$ Understand & $\square$ Read & $\square$ Write \\
\hline & $\square$ Speak & $\square$ Understand & $\square$ Read & $\square$ Write \\
\hline & $\square$ Speak & $\square$ Understand & $\square$ Read & $\square$ Write \\
\hline
\end{tabular}

